\title{
RINGS MADE OF TWISTED WIRE AND THEIR IMITATIONS FOUND IN TRANSILVANIA, CRIȘANA, BANAT, AND DOBRUDJA (10TH - 12TH CENTURIES)
}

\author{
Silviu Oța
}

DOI: 10.17846/CL.2017.10.2.98-113

\begin{abstract}
OȚA, Silviu. Rings Made of Twisted Wire and Their Imitations Found in Transilvania, Crișana, Banat, and Dobrudja (10th - 12th Centuries). The purpose of this paper is to analyse the rings made of twisted wire and cast specimens imitating the twisted ones. Such adornments were discovered in 40 sites situated in the area of 33 nowadays settlements. The rings, made of gold, silver and bronze, were mostly found in funerary structures, less in treasures or accidental discoveries. In order to gather more information about this type of jewellery, I have analysed the burials in which were deposited, the chronology of the cemeteries, the funerary rite, rituals and other adornments that have been associated with the above mentioned rings. The association, in some cases, of the rings with coins provides significant data regarding the absolute chronology of the items. The way such adornments were manufactured, the patterns and the territorial distribution were discussed too. Finally, I have tried to answer to the complicated question regarding the origin of such rings. Taking into account their territorial distribution, I believe that such rigs were rather a fashion than markers of a certain funerary horizon.
\end{abstract}

Keywords: twisted wire, ring, cast, grave, silver, bronze, gold

\begin{abstract}
Abstrakt: OȚA, Silviu. Prstene z tordovaného drôtu a ich imitácie nájdené v Transylvánii, Krišane, Banáte a Dobrudži (10. - 12. storočie). Účelom tohto článku je analyzovat prstene vyrobené $\mathrm{z}$ tordovaného drôtu a liate exempláre prsteňov imitujúce tordovanie. Takéto ozdoby boli objavené na 40 lokalitách situovaných v rámci katastrálneho územia súčasných 33 sídiel. Prstene, vyrobené zo zlata, striebra a bronzu, boli nájdené väčšinou v rámci pohrebných celkov, menej už v depotoch a ojedinelých nálezoch. Kvôli zhromaždeniu väčšieho množstva informácií o tomto type šperkov som analyzoval hroby, v ktorých boli uložené, chronológiu príslušných pohrebísk, pohrebný rítus a obrady, a iné ozdoby, ktoré boli spojené s vyššie spomenutými prsteňmi. Spojenie prsteňov (v niektorých prípadoch) s mincami poskytuje dôležité dáta týkajúce sa absolútneho datovania skúmaných šperkov. Spôsob výroby daných ozdôb, vzory a územné rozšírenie boli v príspevku prediskutované tiež. Nakoniec som sa pokúsil zodpovedat' komplikovanú otázku týkajúcu sa pôvodu pojednávaných prsteňov. Ak zoberiem do úvahy ich územné rozšírenie, domnievam sa uvedené prstene boli skôr módou než znakmi určitého horizontu pochovávania.
\end{abstract}

Klúčové slová: tordovaný drôt, prsteň, odlievanie, hrob, striebro, bronz, zlato

The issue of the twisted wire rings and their imitations. The rings manufactured from twisted wire and their imitations have been fairly little analysed in Romanian archaeology, as such items are a constant presence only in cemeteries of the Carpathian Basin cemeteries. A recent study by 
Lászlo Kóvács demonstrates that these rings are also made of twisted wires (Kovács 2015, 198$205)^{1}$. However, overall, they were regarded as items of probable Byzantine tradition (Dumitriu 2001, 30-31, 52) or from the area of the Bjelo Brdo culture (Dragotă 2006, 74-76), without providing any explanation in one way or another.

In Central and East-Central Europe, the issue was treated differently in regard to the frequency of these items in one necropolis to another (Demo 2009a, 515; Giesler 1981; Váňa 1954, 51-104). Generally, the idea is that they are rather local adornments than items brought here by a particular population. Their distribution area is extremely broad and develops on a sufficiently long chronological interval, namely at least from the tenth century until the thirteenth century.

If we consider the items from cemeteries investigated in wide areas of South-Eastern Europe, one can see that these rings are not numerous and are mainly concentrated in the Carpathian Basin, Southern Poland, Croatia, while they are rare in the south of the Lower Danube and absent in the area located to the south and east of the Carpathian Mountains. Moreover, they are absent from most cemeteries in which prevail the Byzantine adornments from the north of the Danube, dated to the eleventh-thirteenth centuries, investigated on the territory of Banat.

Interestingly, they are used only to a small extent on the territory of the Byzantine Empire, although the only gold items in the South-Eastern Europe (the hoard of Garvăn-Dinogetia) originate from here. In the north-west and west parts of Dobrogea, they were found both in cemeteries and settlements.

At first glance, one can see that these adornments have a quite different chronology, from one region to another. Thus, it seems that the earliest items came from the western part of the Balkan Peninsula, from the Croatian space (Jelovina 1976; Petrinec 2009) and from Slovenia, i.e. from the area of the Köttlach culture (Korošec 1979a; 1979b), but we have a fairly early item also in Dobrogea, dated to the tenth century.

J. Giesler, one of those who attempted to study in detail the cemeteries in the Carpathian Arch, believed that they have emerged in the area of the Bjelo Brdo culture, in the eleventh century (Giesler 1981, 136, 145).

Type of discoveries (Pl. 1). On the territory of Romania and Serbian and Hungarian Banat, the twisted wire rings and their imitations have been found so far in Transylvania, Banat, Crișana and Dobrogea. At the current stage of research they originate from hoards (Garvăn-Dinogetia) and funerary discoveries (comprising 29 cemeteries with registered graves) ${ }^{2}$, and they are supplemented by from cemeteries from which only the inventories were recovered - Zimandul Nou (Gáll 2013a, 552; 2013b, 300. tábla/15, 16, 301. tábla/1), Pădureni (Gáll 2013a, 478, 2013b, 259. tábla/2), Alba Iulia-Termele romane, Botoš-Mlaka (Stanojev 1989, 30), Kikinda-Galad Vincaid (Girić 1995-1996, 150), Mokrin (Kovács 1991, 410), Sânicolaul Mare (Kühn 1911, 183), and from settlements - Dăbâca-Fortress, Area I-II (Gáll 2013, 204, pl. 13/6-7), Garvăn-Dinogetia (Ștefan et al. 1967, 285, fig. 170/35-38, 43-46, 288, 290).

Before, many archaeologists confused the interwoven wire rings with the twisted wire rings.

2 Alba Iulia-Catholic Cathedral, Alba Iulia-Stația de Salvare, Alba Iulia-Str. Brândușei, Alba Iulia-Termele romane, Banatsko Arandjelovo-The 16th of June 1903, Banatsko Arandjelovo-Mound to the north-east of the train station 1903 (Aurel Török), Botoš-Mlaka, Cladova-Dealul Carierei, Cluj-Napoca-Mănăștur, Dăbâca, Deszk-D, Drăușeni, Dudeștii Vechi-Movila lui Dragomir, Duplijaja, Felnac, Foieni, GarvănDinogetia, Geoagiu de Jos, Hodoni-Pocioroane, Hunedoara-Dealul cu Comori, Isaccea, KikindaGalad Vincaid, Kikinda-Vešalo, Kiszombor-B and C, Klárafalva-B, Klárafalva-Faragó, Majdan, Mokrin, Moldovenești, Nikolinci, Oradea-Salca Ghețărie, Ostrov-Piatra Frecăței, Pâclișa, Peteni, Pojejena-Șușca, Rábé-Railway station, Sânicolaul Mare, Starčevo-Livade, Streisângeorgiu, Szőreg-Distilerie, VărșandMovila dintre Vii, Vladimirescu, Zăbala, Zimandu Nou. In total, there are 39 locations. 
Considering the fact that these rings especially originate from funerary contexts, we shall mainly discuss the cemeteries.

The funerary rite of all the investigated graves is inhumation.

The disposition and the arrangement of the cemeteries is extremely diverse, without observing a certain rule (burials in flat cemeteries, ${ }^{3}$ burials in ancient tumuli, ${ }^{4}$ in mounds, ${ }^{5}$ in Roman constructions, ${ }^{6}$ tells, ${ }^{7}$ Dacian/medieval fortifications, ${ }^{8}$ sand dunes $)^{9}$. Part of the cemeteries also had a church - Geoagiu de Jos (Petrov 1996, 405, fig. 4, left, up), Alba Iulia-Catedrala Romano-Catolică (Crîngaci-Țiplic - Oța 2007, 31-34), Cladova-Dealul Carierei? (Boroneanț - Hurezan 1987, 70, pl. 3/6), Drăușeni (Dumitrache 1979, 155-198), Duplijaja (Janković - Radičević 2005, 277), Majdan (Trifunović 2012, 210), Garvăn-Dinogetia (Ștefan et al. 1967, 350-356), Streisângeorgiu (Popa 1976, 37-42; 1988, 62), Dăbâca-Grădina lui Tamaș (Gáll 2013, 162).

The orientation of the graves is known for 39 graves from 15 cemeteries. The graves were oriented W-E (25 in 13 cemeteries), ${ }^{10}$ five in four cemeteries were oriented SW-NE ${ }^{11}$ and nine in four cemeteries were oriented NW-SE. ${ }^{12}$

\section{Arrangement of the graves}

The pits. No special arrangements have been reported, except for grave 102 from Alba IuliaStr. Brândușei, which had a stone on both sides of the skull.

The burials are single in most of the cases.

A double burial was recorded only in the cemetery from Alba Iulia-Str. Brândușei, grave 22 . It was a woman with a child in her arms.

The deposition of the deceased was usually made in a simple pit. Traces of boards from the coffin or nails were found only in four cases (Hunedoara-Dealul cu Comori, grave 13 (Roska 1913, 172), grave 20 (Gáll 2013a, 510, Gáll 2013b, 275. tábla/grave 20/1) Zăbala, grave 14 (Székely 1993-1994 (1994), 278), Moldovenești, grave 16 (Roska 1914, 128, 3. kép/11, 130-131) and OstrovPiatra Frecăței, grave 4 (Stănică 2004, 361, 362, pl. IV/5).

The position of the deceased. In all the registered graves the deceased were deposited laying out in the supine position or on the back.

The position of the arms is well known in the case of 37 graves in 15 cemeteries. Position A, with the arms along the body: Cluj-Napoca-Mănăștur, grave 157, 159, Kikinda-Vešalo, grave 1

Most of the cemeteries investigated.

Isaccea, grave 151, 166.

5 Banatsko Arandjelovo-Mound to the north-east of the train station 1903 (Aurel Török), Dudeștii VechiMovila lui Dragomir, Vărșand-Movila dintre Vii.

6 Alba Iulia-Termele romane.

7 Hodoni-Pocioroane.

8 Hunedoara-Dealul cu Comori, Vladimirescu, Dăbâca-Fortress, Area I-II, Cluj-Napoca-Mănăștur, Cladova-Dealul Carierei, Duplijaja.

9 Kikinda-Vešalo.

10 Hunedoara-Dealul cu Comori, grave 13, 39, 43; Alba Iulia-Strada Brândușei, grave 22, 227, 231; Pâclișa, grave 2, 3; Isaccea, grave 25, 80, 166; Drăușeni, grave 5; Hodoni-Pocioroane, grave 15; Kikinda-Vešalo, grave 1; Nikolinci, grave 4; Zăbala, grave 14, 163; Peteni, grave 32; Moldovenești, grave 16, 42, 55; ClujNapoca-Mănăştur, grave 60, 86, 159; Streisângeorgiu, grave 51.

11 Hunedoara-Dealul cu Comori, grave 5; Alba Iulia-Strada Brândușei, grave 200; Dudeștii Vechi-Movila lui Dragomir, grave 1/2000; Zăbala, grave 53, 154.

12 Alba Iulia-Strada Brândușei, grave 137, 121, 102, 101, 68; Isaccea, grave 6, 151; Foieni, grave 32; ClujNapoca-Mănăștur, grave 157. 
(Girić 1995-1996, 149), Vărșand-Movila dintre Vii, grave 56 (Popescu 1956, 132); Position B, with the arms along the body and the palms placed on the pelvis: Alba Iulia-Str. Brândușei, grave 200, 231, Isaccea, grave 25 (Vasiliu 1984, 121), Foieni: grave 32, Dudeștii Vechi-Movila lui Dragomir, grave 1/2000 (Bejan et al. 2005, 28, 40, fig. 5/2), Hunedoara-Dealul cu Comori, grave 28, 31, 32, 34, 39, 43, 54 (Gáll 2013a, 511, 512, 513), Streisângeorgiu, grave 51 (Popa 1976, 52, 53, Abb. 12/12, 54; Popa 1988, 62, 65, fig. 13/1-2), Moldovenești, grave 55 (Gáll 2013a, 529); Position C, with the arms bent at the elbow, with the palms on the abdomen: Isaccea, grave 6, 151, 166 (Vasiliu 1984, 117, 128, 129), Moldovenești, grave 16, 42 (Roska 1914, 140), 55 (Roska 1914, 143), HunedoaraDealul cu Comori, grave 20 (Gáll 2013a, 510); Position D, with the arms bent at the elbow, with the palms on the chest: Hunedoara-Dealul cu Comori, grave 5; Position E, with the arms bent at the elbow and the palms placed on the neck, the collarbone or the shoulders; Position $\mathrm{AB}$, with the arms along the body and one palm placed on the pelvis: Alba Iulia-Str. Brândușei, grave 137, 227, Dinogetia, grave 16 (Ștefan et al. 1967, 228, 285, fig. 170/39), Cluj-Napoca-Mănăștur, grave 60; Position AC, with one arm along the body and the second arm bent at the elbow, with the palm on the abdomen: Isaccea, grave 80 (Vasiliu 1984, 124), Pâclișa, grave 2 (Gáll 2013a, 204, Gáll 2013b, 86. tábla/grave 2); Position AD, with one arm along the body and the second arm bent at the elbow, with the palm on the chest: Alba Iulia-Str. Brândușei, grave 101; Position BC, with one arm along the body and the palm placed on the pelvis and the second arm bent at the elbow, with the palm on the abdomen: Ostrov-Piatra Frecăței, grave 4; Position BD, with one arm along the body and the palm placed on the pelvis and the second arm bent at the elbow, with the palm on the chest: Nikolinci, grave 4 (Živković 1997, 144, 154, T. III/G. 4), Garvăn-Dinogetia, grave 23 (Ștefan et al. 1967, 228, 285, fig. 171/1); Position BE, with one arm along the body and the palm placed on the pelvis and the second arm bent at the elbow and the palm placed on the neck, the collarbone or the shoulders: Hunedoara-Dealul cu Comori, grave 13; Position BX, with one arm along the body and the palm placed on the pelvis and the second arm is missing: Cluj-Napoca-Mănăștur, grave 86).

The position of the legs. The legs were stretched and parallel in 25 individuals from ten cemeteries. For the rest of the graves, there were not needed data.

Interventions on the corpses are known in two cases. They are late disarrangements caused occasioned by the erection of walls (Streisângeorgiu, grave 51) or subsequent burials in Drăușeni, grave 5 (Dumitrache 1979, 174).

Funerary offerings are reported only in the necropolis of Ostrov-Piatra Frecăței, grave 4, and consist of a jug.

The anthropological determination of the gender of the deceased is known in the case of six graves in three cemeteries. Overall, they are adult females - Alba Iulia-Str. Brândușei, grave 22 (Dragotă et al. 2009, 31), Nikolinci, grave 4 (Živković 1997, 144), Zăbala, grave 14, 53, 154, 163 (Zoffmann 1993-1994 (1994), 307-326) but also children or adolescents - Hodoni-Pocioroane grave 5, 15 (Muntean 1996, 43-54), Alba Iulia-Strada Brândușei, grave 22, Isaccea, grave 151 (Vasiliu 1984, 128).

There are relatively few inventory items associated to the rings and they consist of adornments and clothing accessories. The adornments consist of simple hair links - Moldovenești, grave 16, 42, 55, Hodoni-Pocioroane, grave 5, 15 (Bejan - Moga 1979, 159; Țeicu 1996, 36-37), Isaccea, grave 25, 166, Alba Iulia-Str. Brândușei, grave 121, Hunedoara-Dealul cu Comori, grave 13; hair links with one S-shape bent end - Alba Iulia-Str. Brândușei, grave 68, 102, 121, 200, 227, Alba Iulia-Catedrala 
Romano-Catolică, grave 5, 209-? and other two graves, Zăbala, grave 14, 53, 163 (Székely 19931994 (1994), 278, 280, 283), Cluj-Napoca-Mănăștur, grave 157, 160, Kiszombor-B, grave 122, 414 (Fehér - Éry - Kralovánszky 1962, 48), Pâclișa, grave 2, Dudeștii Vechi-Movila lui Dragomir, grave 1/2000, Kiszombor-C, grave 22 (Fehér - Éry - Kralovánszky 1962, 48), Klárafalva-Faragó, grave 10 (Fehér - Éry - Kralovánszky 1962, 49), Streisângeorgiu, grave 51; torques - Moldonenești, grave 42; beads - Isaccea, grave 70 (Vasiliu 1984, 123), 80, 151, Kiszombor-B, grave 414, Ostrov-Piatra Frecăței, grave 4, Hodoni-Pocioroane, grave 15 (Țeicu 1996, 36); finger rings - Isaccea, grave 151, Alba Iulia-Str. Brândușei, grave 22, Hunedoara-Dealul cu Comori, grave 43, Nikolinci, grave 4 (Živković 1997, 144, 154, T. III/8), Vărșand-Movila dintre Vii, grave 56; bracelets - Isaccea, grave 6, 151, Moldovenești, grave 16, 42, Alba Iulia-Str. Brândușei, grave 137).

The clothing accessories are limited to buttons (Ostrov-Piatra Frecăței, grave 4); pendants (Kiszombor-B, grave 122), and buckles - Kiszombor-C, grave 22, Peteni, grave 32 (Székely 2012, 231).

Knives were reported in three graves from three cemeteries (Alba Iulia-Str. Brândușei, grave 137, Kiszombor-B, grave 1, Moldovenești, grave 55).

The coin found in the graves ensures absolute chronology. Coins were discovered in 12 cemeteries, in the case of 16 graves - Alba Iulia-Str. Brândușei, grave 137, 200, 231, Zăbala, grave 53, 154, 163 (Székely 1993-1994 (1994), 280, 283) Alba Iulia-Catedrala Romano-Catrolică, grave 5, Banatsko Arandjelovo-The 16th of June, 1903, grave 2 (Oța 2008, 219, with the bibliography), HunedoaraDealul cu Comori, grave 39, Kiszombor-B, grave 414, Kiszombor-C-grave 22, Klárafalva-B, grave 53, Moldovenești, grave 55, Ostrov-Piatra Frecăței, grave 4, Pâclișa, grave 2, Peteni, grave 32. The monetary issues are Hungarian (discovered in 12 graves) and Byzantine (grave 4 from Ostrov-Piatra Frecăței, Michael IV's issue and one follis). The issuer is unknown for three other items (Kiszombor-C, grave 22, Klárafalva-B, grave 53 (Fehér - Éry - Kralovánszky 1962, 49) and Peteni, grave 32. The Hungarian items were issued during the reign of Kings Stephen I (1000 1038; Hunedoara-Dealul cu Comori, grave 39, Alba Iulia-Str. Brândușei, grave 137, Pâclișa, grave 2), Andrew I (Alba Iulia-Str. Brândușei, grave 137, 200, 231, Kiszombor-B, grave 414-?), Solomon (Banatsko Arandjelovo- The 16th of June, 1903, grave 2, Kiszombor-B, grave 414-?), Ladislaus I (1077 - 1095; Banatsko Arandjelovo-The 16th of June, 1903, grave 2, Moldovenești, grave 55), Coloman (1095 - 1116; Alba Iulia-Catedrala Romano-Catolică, grave 5), and Stephen III (Zăbala, grave $53,103,154)$. They are supplemented by the $1 / 2$ silver denar discovered in grave 32 from Peteni.

Materials and techniques of execution. The execution technique of the items is not mentioned in any excavation report. According to the drawings, several possibilities become rather obvious, depending on the manufacturing of the items, namely they were twisted and moulded.

I. The twisted wire items (from a wire which is put in three). With regard to the materials they were manufactured of, they are made of gold, silver, bronze and they are gold-plated.

I.1. A gold item originates from the hoard of Garvăn-Dinogetia (Pl. 2/I.1.). Among the gold wires, other thinner, filigree wires, were introduced. The ends are beaten, circular in section and thinned.

The dating was made based on the absolute and relative chronology. The two rings were found in association with coins issued during the Emperors Basil II and Constantine VIII (976 - 1025), Empress Theodora (1055 - 1056) and Emperor Isaac Komnenos (1057 - 1059). 
I.2. The silver rings were discovered in 24 investigated or destroyed cemeteries and in the case of 28 registered graves. ${ }^{13}$

Based on their manufacturing type, we can distinguish rings made of:

I.2.1. Triple twisted wire. ${ }^{14}$ Several models are included here.

I.2.1.1. The ends are simple, sharpened, and among the wires there are other thinner, filigree wires (Garvăn-Dinogetia, grave 16; Pl. 2/I.2.1.1.).

I.2.1.2. The ends are usually simple, without a visible loop (Pl.2/I.2.1.2.) - Banatsko ArandjelovoMound excavated to the north-east of the train station 1903 (Aurel Török), one item (Oța 2008, 218, pl. 42/9); Alba Iulia-Str. Brândușei, grave 68, 101, 102; Hodoni-Pocioroane, grave 15; BotošMlaka (Stanojev 1989, 30, 31/165); Zimandul Nou (Gáll 2013a, 552; 2013b, 300. tábla/16, 301. tábla/1); Pâclișa, grave 5; Garvăn-Dinogetia, grave 23 and another one from fortification; Alba Iulia-Catedrala Romano-Catolică, grave 5 and three items from graves without number; Alba Iulia-Termele Romane, five items; Foieni (Németi 2001, 228, 3. kép/3, 233).

I.2.1.3. The ends are elongated loop-shaped (Pl. 2/I.2.1.3.) - Zăbala, grave 14; Streisângeorgiu, grave 51; Ostrov-Piatra Frecăței, grave 4; Majdan, two items (Trifunović 2012, 209, T. 139/4, 5, 210); Alba Iulia-Catedrala Romano-Catolică, grave 205 and one grave without number; HunedoaraDealul cu Comori, grave 13, 39; Cluj-Napoca-Mănăștur, M.157; Moldovenești, grave 16, 55; Alba Iulia-Str. Brândușei, grave 121, Alba Iulia-termele Romane, two items.

I.2.1.4. The ends are overlapping, beaten, circular in section (Pl. 2./I.2.1.4.) -Banatsko Arandjelovo-Mound excavated to the north-east of the train station 1903 (Aurel Török), two items (Oța 2008, 218, pl. 42/5, 7); Alba Iulia-Termele Romane, six items.

I.2.1.5. The ends are cut (Pl. 2/ I.2.1.5.)-Pojejena-Șușca, grave 1 (Oța 2008, 275, pl. 98/6).

In the absence of a minimal description, no other observations can be made about the items recovered from the other cemeteries.

I.3. Bronze wire rings. They were found in seven registered graves within eight cemeteries.

I.3.1. From a wire which is put in two and twisted. We have two models.

I.3.1.1. From a wire which is put in two and twisted (Garvăn-Dinogetia, two items). Just a termination have buckle (Pl. 3/ I.3.1.1.).

I.3.1.2. From two wires (Pl. 3/ I.3.1.2.), without loops (Dudeștii Vechi-Movila lui Dragomir, G1/2000).

Another ring was found in Geoagiu de Jos, grave 10, but the metal is not specified.

I.3.2. From a wire which is bent in two places.

13 Hunedoara-Dealul cu Comori, grave 13, 39; Alba Iulia-Str. Brăndușei, grave 68, 101, 102, 121; Pâclișa, grave 18, Isaccea, grave 6, 25; Pojejena-Șușca, grave 1; Banatsko Arandjelovo-Mound to the north-east of the train station 1903 (Aurel Török); Botoš-Mlaka; Hodoni-Pocioroane, grave 15; Klárafalva-B, grave 31, 53; Klárafalva-Faragó, grave 10; Mokrin, Majdan; Ostrov-Piatra Frecăței, grave 4; Zăbala, grave 14; Garvăn-Dinogetia, grave 16, 23 and from a settlement; Moldovenești, grave 16, 25; Foieni; Cluj-NapocaMănăștur, grave 60, 86, 157, 159; Streisângeorgiu, grave 51; Alba Iulia-Stația de Salvare, grave 12; Vladimirescu; Alba Iulia-Catholic Cathedral, grave 5, 209 and other four graves without number; Alba Iulia-Termele romane and Zimandu Nou (two items).

14 Garvăn-Dinogetia, Banatsko Arandjelovo, Hodoni-Pocioroane, Zăbala, Streisângeorgiu, Ostrov-Piatra Frecăței, Alba Iulia-Catholic Cathedral, Pojejena-Șușca, Alba Iulia-Str. Brândușei, Drăușeni, Majdan, Hunedoara-Dealul cu Comori, Cluj-Napoca-Mănăștur, Moldovenești, Botoš-Mlaka, Pâclișa, Klárafalva-B, Klárafalva-Faragó, Mokrin, Alba Iulia-Staţia de Salvare, Vladimirescu, Alba Iulia-Termele Romane. 
I.3.2.1. The ends are simple, without visible loops (Pl. 3/ I.3.2.1.) - Isaccea, grave 80; Pâclișa, grave 2 and another one; Garvăn-Dinogetia; Pădureni (Gáll 2013a, 478; 2013b, 259. tábla/2); Hodoni-Pocioroane, grave 5 (Țeicu 1996, 36, 40); Felnac (Gáll 2013a, 110; 2013b, 24. tábla/17).

I.3.2.2. The wire is bent in two places (Pl. I.3.2.2.), with ends fitted with elongated loops Garvăn-Dinogetia, grave 25 (Ștefan et al. 1967, 288, 285, fig. 170/42).

I.3.2.3. Similar rings (Pl. 3/I.3.2.3.), but in the loops we can observed the termination of the wire (Isaccea, grave 78; Garvăn-Dinogetia, three items).

There are also several deformed items from Garvan-Dinogetia (Pl. 3) (Ștefan et al. 1967, 285, fig. 170/35, 288) and Felnac (Gáll 2013a, 110; 2013b, 24. tábla/13).

II. The twisted wire items (double twisted wire, then again doubled and twisted). ${ }^{15}$ With regard to the materials they were made of gold, silver and bronze.

II.1. The gold item (the hoard of Garvăn-Dinogetia) manufactured of four wires has its ends beaten, circular in section and thinned (Pl. 3/II.1.). The dating is made similarly to the item made of twisted gold wires.

II.2. The gold-plated silver ring originates from the necropolis in Alba Iulia-Str. Brândușei, grave 137 (Pl. 3/II.2.). Its ends are beaten, circular in section. The dating can be based on the absolute chronology, as the ring was found near a coin issued during the reign of King Andrew I $(1046$ - 1060).

II.3. The silver items (Pl. 3/II.3.) originate from the cemeteries at Banatsko ArandjelovoMound excavated to the north-east of the train station 1903 (Aurel Török) (Stanojev 1989, 15, 17/28), Foieni, Satu Mare County (Németi 2001, 228, 3. kép/5, 233), Drăușeni, grave 5 (Dumitrache 1979, 174, 175, fig. 9/5), Vărșand-Krammer`s excavations (Gáll 2013a, 210; 2013b, 90. tábla/6), Zimandul Nou (Gáll 2013a, 552; 2013b, 300. tábla/15) and Cluj-Napoca-Mănăștur (grave 60, 86, 159). The dating can be based on the earrings with one S-shaped bent end and without incised lines, namely to the eleventh century.

II.4. Five items are reported as manufactured of bronze wires (Pl. 3/II.4.), namely the following ones in grave 57 from Klárafalva-B; grave 3 from Szőreg-Distilerie (Fehér - Éry - Kralovánszky 1962, 76); grave 22 from Kiszombor-C; Dăbâca-Grădina lui Tamaș (Gáll 2013, 168, 200, pl. 9/7) and grave 166 from Isaccea but they were not published with an illustrations. The ring from Isaccea is an exception. Unfortunately, only one grave (Kiszombor-C, grave 22) had half of an undeterminable coin. The items found in association do not help much in obtaining a more exact chronology. They consist of a buckle and a hair link with one S-shaped bent end.

About other items from nine cemeteries or settlements can be stated that the material from which they were made is unknown - Zimandul Nou; Banatsko Arandjelovo-The 16th of June, 1903, grave 2; Deszk-D; Felnac; Kiszombor-B, grave 1; Sânicolaul Mare; Szőreg-Distilerie, grave 3; Garvăn-Dinogetia; Isaccea. The absolute chronology places them in the eleventh century, based on the coins issued during the reigns of King Solomon (1063 - 1074) and Ladislaus I (1077 - 1095). Unfortunately, without knowledge of the material and in the absence of the illustration regarding most of the graves, the presence of the coins is helpful only to conclude that such adornments made of braided wires were still in use during the last quarter of the eleventh century.

In formal terms, one can see that there are several models of these rings. Their territorial distribution especially covers the area inside the Carpathian Arch and Dobrogea.

III. The casted items were discovered in 18 registered graves from 16 cemeteries, namely in Kiszombor-B, grave 122, 180, 251, 414 (Fehér - Éry - Kralovánszky 1962, 48), Kiszombor-C,

15 These items have the appearance of interwoven wires. 
grave 22 and Kiszombor-Juhászhalom, grave 1 (Fehér - Éry - Kralovánszky 1962, 48, 49; OradeaSalca Ghețărie, grave I/11, grave V/15 (Harhoiu - Gáll - Lakatos 2010, 90, 91, 116, pl. 6/G. I (11)/2, G. V (15)/15, 16); Nikolinci, grave 4, one silver item (Živković 1997, 144, 154, T. IIIG. 4/9); Hunedoara-Dealul cu Comori, grave 5, 43 (Roska 1913, 170, 3. kép/11, 16, 171, 178), 39, 54 (Gáll 2013a, 512, 514; 2013b, 276. tábla/G. 39/1, 2, 277. tábla/G. 54/1); Zăbala, grave 154 (Székely 1993-1994 (1994), 283); Alba Iulia-Str. Brândușei, grave 22 (Dragotă et al. 2009, 31, 225/G. 22/1); Alba Iulia-Termele Romane (Horedt 1958, 60, Abb. 17/2-4, 69); Vladimirescu, grave 57 (Zdroba - Barbu 1976, 6, 53); Foieni, grave 32 (Németi 2001, 228, 3. kép/4, 233); Moldovenești, grave 42 (Roska 1914, 140, 141, 7. kép/3); Dăbâca-Fortress, Area IV-? (Gáll 2013, 183, 204, pl. 13/7; 2013a, 477; 2013b, 259. tábla/4); Rábé-Railway station (Kovács 1991-1992 (1992), 61, 14. kép/13); Vărșand-Movila dintre Vii, one item from bronze (Gáll 2013a, 211; 2013b, 93. tábla/5) and Starčevo-Livade (Djordjević - Djordjević 2012, 82, fig. 9/1).

They were assigned to the funerary horizon of the Bjelo Brdo type. The rings in the above mentioned cemeteries were found in association with hair links with one S-shaped bent end, beads, coin, buckle, pendant, therefore a relative chronology can be provided, from the late tenth century and the eleventh century. In terms of absolute chronology, we have only one item found in association with a coin issued during the reign of Kings Andrew I (1046 - 1060) or Solomon $(1063-1074)$.

With regard to the manufacturing material, the casted items are made of:

III.1. Silver-Alba Iulia-Str. Brândușei, grave 22; Nikolinci, grave 4; Hunedoara-Dealul cu Comori, grave 5, 43; Foieni, grave 32 (Németi 2001, 228, 3. kép/4, 233).

III.1.1. The first sub-group includes the items with oblique grooves. Based on the type of section, we have these items there:

III.1.1.1. The item from Nikolinci, grave 4, circular in section (Pl. 4/III/1).

III.1.1.2. The item (Pl. 4/III/2) in grave 22 from Alba Iulia-Str. Brândușei, semicircular in section, and grave 5 from Oradea-Salca-Ghețărie (Harhoiu et al. 2010, 91, 116, G. V/15).

III.1.2. The second sub-group includes the items with grooves perpendicular to the link:

III.1.2.1. With distanced grooves Pl. 4/III.1.2.1.) (Hunedoara-Dealul cu Comori, grave 5, Foieni, grave 32).

III.1.2.2. With very close grooves (Pl. 4/III.1.2.2.) (Hunedoara-Dealul cu Comori, grave 43).

We do not have coins for any of the items. A good dating element remains the casted bracelet, decorated toward the ends with zoomorphic motifs, which can be dated from the beginning of the eleventh century to the end of the same century (Kovács 1994, 137).

III.2. Rings from bronze (from four cemeteries, only one grave is reported) ${ }^{16}$.

All the published items had grooves perpendicular to the link. They are:

III.2.1. Distanced - Rábé-Railway station (Pl. 4/III.2.1); Oradea-Salca Ghețărie, grave I (Harhoiu et al. 2010, 90, 116, G. I/1), grave 5 (Harhoiu et al. 2010, 91, 116, G. V/16); Moldovenești, grave 43 .

III.2.2. Very close (Pl. 4/III.2.2.) - Starčevo-Livade (Djordjević - Djordjević 2012, 82, fig. 9/1); Dăbâca (Gáll 2013a, 477; 2013b, 259. tábla/4) and Moldovenești, grave 42.

The items from Vladimirescu were published without images or description. None of the items was discovered in association with coins. The inventory of grave 42 from Moldovenești included a torques from twisted wires and two bracelets. The torques (Ib, according to the classification proposed by Giesler 1981, 136, 145) can be dated from the last quarter of the tenth century to

16 Moldovenești, grave 42; Vladimirescu; Starčevo-Livade; Rábé-Railway station. 
the middle of the following century. The ring was regarded to originate from around the 30 s of the eleventh century. Even if we take in consideration only these two elements, the grave with its inventory must approximately be dated to the middle of the eleventh century.

III.3. Unspecified material. These items can be divided into in two groups.

II.3.1. With oblique incised lines - Alba Iulia-Termele Romane, one item (Horedt 1958, 60, Abb. 17/3); Kiszombor-B, grave 122, 251, 41417.

II.3.2. With incised lines perpendicular to the link - Alba Iulia-Termele Romane, two items (Horedt 1958, 54, 60 Abb. 17/2, 4); Dăbâca-Fortress, Area IV-? (Gáll 2013, 183, 202, pl. 13/7) and probably Kiszombor-B, grave 180 .

However, a coin issued during the reign of Kings Andrew I (1046 - 1060) or Solomon (1063 1074) was found in grave 414 from Kiszombor-B.

\section{Conclusion}

The presence of the referred items on the territory of Romania reflects rather a fashion trend. It cannot have a particular ethnic feature.

The beginnings of their use should be sought at least during the tenth century. The absolute chronology, based on the coins found inside the graves, indicates the use of the items from the reign of King Stephen I to the reign of King Stephen III.

It has been observed that inside the graves they usually occurred on the right hand fingers of the deceased. The anthropological analysis and the association with other inventory items indicate their presence especially in graves of women and sporadically in graves of children or adolescents.

Overall, one can notice the absence of weapons inside the graves, except for three graves in which knives were deposited.

In terms of items in the cemeteries, it can be noticed that, regardless of region, Byzantine items or their imitations also occur almost invariably. However, they are hardly ever associated with items derived from the ones of the steppe horizon of the tenth century. Exceptions are some graves that had these rings as grave goods.

This could indicate that the twisted rings and their imitations are a commodity or a local product that reflects the preference of some communities which used this type of adornments.

The fact that there are more models in a region, even of different materials, indicates the activity of several workshops. The presence of large numbers of such adornments in the area of Alba Iulia indicates the existence of a major manufacturing centre. Another identifiable centre appears to be at Garvăn-Dinogetia.

Another concentration of rings made of twisted wires can be observed in the Szeged area, so we can suppose there it was a possible centre of their production.

English translation: Alexandra Decu

\section{Bibliography}

Bejan, Adrian - Moga, Marius. 1979. Necropola feudal timpurie de la Hodoni (jud. Timiş). In Tibiscus 5, 155-168.

17 The items from Kiszombor-B (grave 122, 180, 251 and 414) were not described or published with images. 
Bejan, Adrian - Tănase, Daniela - Gáll, Erwin - Kalcsov, Constantin. 2005. Necropola medievală timpurie de la Dudeştii Vechi-"Movila lui Dragomir" (Jud. Timiş). In Arheologia Medievală $5,27-43$.

Boroneanț, Vasile - Hurezan, Gheorghe, Pascu. 1987. Cimitirul din secolele XI-XII de la Cladova, jud. Arad. In Ziridava 15-16, 67-74.

Crîngaci-Țiplic, Maria - Oța, Silviu. 2007. Archäologisches Material aus dem 12. Jahrhundert der Fundstelle: Römisch-katholische Kathedrale Karlsburg/Alba Iulia, im der Sammlung des Nationalen Geschichtemuseums Rümaniens. In Forschungen zur Volks- und Landeskunde 50, 31-61.

Demo, Željko. 2009a. Ranosrednjovjekovno groblje bjeolobrdske kulture:Vukovar - Lijeva bara (X-XI. stoljéce). Zagreb.

Demo, Željko. 2009b. Ranosrednjovjekovno groblje bjeolobrdske kulture: Vukovar - Lijeva bara (X-XI. stoljéce). Zagreb.

Djordjević, Jelena - Djordjević, Vojislav. 2012. Preliminary Results of Archaeological Research at the Medieval Site of Starčevo-Livade 2008-2010. In Proceding of the Regional Conference. Research, Preservation and Presentation of Banat Heritage: Current State and Long Term Strategy, Vršac, Serbia, 17-19 November 2011, 75-84.

Dragotă, Aurel. 2006. Aspecte de multiculturalitate spirituală. Rit şi ritual funerar in Transilvania şi Europa Centrală şi de Sud-Est (sec. IX-XI p. Ch.). Alba Iulia.

Dragotă, Aurel - Rustoiu, T. Gabriel - Drâmbărean, Matei - Deleanu, Valentin - Oța, Silviu. 2009. Necropola medieval-timpurie de la Alba Iulia-Str. Brândușei. Cercetările arheologice din anii 1997-2008. Alba Iulia. Collection Biblibliotheca Mvsei Apulensis, XXIII. Alba Iulia.

Dumitrache, Mariana. 1979. Cetatea sătească din Drăușeni, jud. Brașov, ansamblu de arhitectură medievală. Cercetări arheologice 1973-1977. In Cercetări Arheologice (Muzeul Național de Istorie) 3, 155-198.

Dumitriu, Luminița. 2001. Der Mittelalterliche Schmuck des Unteren Donaugebietes im 11. - 15. Jahrhundert. Bucharest.

Fehér, Géza - Éry, Kingá - Kralovánszky, Alán. 1962. A közep-Duna-medence magyar honfoglaláses kora Árpád-kori Sírleletei. Leletkataszter. In Régészeti Tánulmányok II, Budapest.

Gáll, Erwin. 2013. Dăbâca: necropola din jurul bisericii din Grădina lui A. Tămaș. Câteva idei privind evoluția habitatului de la Dăbâca. In Analele Banatului S. N. 21, 159-210.

Gáll, Erwin. 2013a. Az Erdély-medence, a Partium és a Bánság 10-11. Századi temetői, szórványes kincsleletei. Szeged.

Gáll, Erwin. 2013b. Az Erdély-medence, a Partium és a Bánság 10-11. Századi temetői, szórványes kincsleletei. Szeged.

Giesler, Jochen. 1981. Untersuchungen zur Chronologie der Bijelo Brdo Kultur. Ein Beitrag zur Archäologie des 10. und 11. Jahrhunderts im Karpatenbecken. In Praehistorische Zeitschrift 56/1, Berlin - New York, 4-167.

Girić, Milorad (1995/1996). Severni Banat-sakralni objekti i nekropole 10-15. Veka. In Rad Muzeja Vojvodine 37-38, 139-154.

Harhoiu, Radu - Gáll, Erwin - Lakatos, Attila. 2010. Fragmente de necropole de la Oradea-Salca Ghețărie din secolele VI și X-XI. In Materiale și Cercetări Arheologice 6, S. N., 83-132.

Horedt, Kurt. 1958. Untersuchungen zum Frühgschichte Siebenburgens. Bucharest.

Iambor, Petru. 2005. Așezări fortificate din Transilvania: secolele IX-XIII. Cluj-Napoca.

Janković, Djordje - Radičević, Dejan. 2005. The stronghold from Duplijaja, a medieval archaeological discovery. In Banatica 17, 275-285.

Jelovina, Dušan. 1976. Starohrvatske nekropole. Na području izmedju Rijeka Zrmanje i Cetine. Split. 
Korošec, Paola. 1979a. Zgodnjesrednjeveška arheološka slika karantanskih slovanov, 1. Ljubljana. Korošec, Paola. 1979b. Zgodnjesrednjeveška arheološka slika karantanskih slovanov, 2. Ljubljana. Kovács, László. 1991. Bemerkungen zur Arbeit von N. Stanojev: Nekropolen aus dem 10.-15. Jahrhundert in der Vojvodina. 712 Katalogabschnitte. Katalog 1. In Acta Archaeologica Academiae Scientiarum Hungaricae 43/3-4, 399-424.

Kovács, László. 1991/1992 (1992). A Móra Ferenc Múzeum néhány régi, 10-11. századi leletanyagáról: Oroszlámos, Horgos, Majdán, Rábé, (Csóka). In Évkonive Szeged 1, 37-74 and plates.

Kovács, László. 1994. Das Früharpadenzeitliche Gräberfeld von Szalbocs. In Varia Archaeologica Hungarica VI. Budapest.

Kovács, László. 2015. A Taktaköz 10-11.századi sír-és szórványleletei valamint. A tiszalúc sarkadi 11. századi temető. Szeged-Budapest.

Kühn, Léo. 1911. Középkori temetöröl Nagyöszön. In Archaeologiai Értésítő 31, 182-183.

Muntean, Marius. 1996. Studiul antropologic din necropole feudală timpurie de la Hodoni. In Drașovean, Florin - Țeicu, Dumitru - Muntean, Marius (eds.). Hodoni. Locuirile neolitice și necropola medievală timpurie. Reșița. 43-54.

Németi, János. 2001. A mezőfényi (Foieni) Árpád-kori temetőrész rövid áttekintése. In Évkonive Nyíregyházi XLIII, Évfolyam, 225-238.

Oța, Silviu. 2008. Orizonturi funerare din Banatul istoric (secolele X-XIV). Alba Iulia. Collection Bibliotheca Brukenthal, XXVIII. Sibiu.

Petrinec, Maja. 2009. Graberfelder aus dem 8. bis 11. Jahrhundert im Gebiet des fruhmittelalterlichen kroatischen Staates, (Ed. Tomislav Šeparović), Zagreb - Split.

Petrov, Gheorghe. 1996. Raport preliminar asupra cercetărilor arheologice din complexul medieval de la Geoagiu de Jos, jud. Hunedoara (campaniile din 1993, 1994, 1995). In Acta Musei Napocensis 33/I, 403-410, fig. 1-4.

Popa, Radu 1976. Streisîngeorgiu. Ein Zeugnis rumänischer Geschichte des 11. - 14. Jahrhunderts in Süden Transsilvaniens. In Dacia N. S. XX, 37-61.

Popa, Radu. 1988. La începuturile Evului Mediu Românesc. Țara Hațegului. București.

Popescu, Dorin. 1956. Cercetări arheologice în Transilvania (I-IV). In Materiale și Cercetări Arheologice II, 41-250.

Roska, Márton. 1913. Árpádkori temető Vajdahunyadon. In Dolgozatok Cluj IV/1, 166-198.

Roska, Márton. 1914. Árpádkori temető Várfalván. In Dolgozatok Cluj V/1, 125-187.

Sokol, Vladimir. 2016. Medieval Jewelry and Burial Assemblages in Croatia. A Study of Graves and Grave Goods, ca. 800 to ca. 1450. In Curta, Florin (ed.). ECEEMA 36, Leiden-Boston.

Stanojev, Neboiša. 1989. Nekropole X-XV veka u Vojvodini. 712 Kataloških jedivica. Novi Sad.

Stănică, Aurel. 2004. Câteva aspecte privind așezarea medio-bizantină de la Ostrov-Piatra Frecăței (Beroe), jud. Tulcea. In Cândea, Ionel - Sîrbu, Valeriu - Neagu, Marian (eds.). Prinos lui Petre Diaconu la 80 de ani. Brăila - Călărași, 357-372.

Székely, Zoltan. 1993-1994 (1994). A zabolai (Zăbala-România) kora-középkori temető embertani anyaga. In Veszprém Megyei Múzeumok Közleményei 19-20, 277-305.

Székely, Zoltan. 2012. Necropola medievală de la Peteni (com Zăbala, jud. Covasna). In Lucrări alese. Sfântul Gheorghe, 230-238.

Ştefan, Gheorghe - Barnea, Ion - Comșa, Maria - Comșa, Eugen. 1967, Dinogeția. I. Așezarea feudală timpurie de la Bisericuța-Garvăn. Bucharest.

Trifunović, Stanko. 2012. Majdan. In Stanko Trifunović (ed.). Arheološka topografija Banata 1. Opština Novi Kneževac. Novi Sad. 203-253.

Țeicu, Dumitru. 1996. Necropola din secolul al XI-lea de la Hodoni. In Hodoni. Locuirile neolitice și necropola medievală timpurie. Reșița, 34-43. 
Váňa, Zdeněk. 1954. Madaři a Slované ve světle archeologických nalezů X.-XII. století. In Slovenská Archeológia II, 51-104.

Vasiliu, Ioan. 1984. Cimitirul feudal-timpuriu de la Isaccea. In Peuce IX, 107-141, 519-540.

Zdroba, Mircea - Barbu, Mircea 1976. Săpăturile arheologice de la Felnac și Vladimirescu (Rapoarte preliminare). In Ziridava 6, 47-55.

Živković, Jasmina. 1997. Neka nova otkrića u južnom Banatu. In Rad Muzeja Vojvodine 3, 143-154. Zoffmann, Zsuzsana. 1993-1994 (1994). A Zabola (Zăbala-România) lelőhelyen feltárt bronzkori sír és Árpad-kori temető embertani anyaga. In A Veszprém Megyei Múzeumok Közleményei 19-20, 307-326.

SUMMARY: RINGS MADE OF TWISTED WIRE AND THEIR IMITATIONS FOUND IN TRANSILVANIA, CRIȘANA, BANAT, AND DOBRUDJA (10TH - 12TH CENTURIES). The rings manufactured from twisted wire and their imitations have fairly little been analysed in the Romanian archaeology, as such items are constantly present only in the Carpathian Basin cemeteries. In Central and East-Central Europe, the issue was treated differently in regard to the frequency of these items in one necropolis to another. Generally, the idea is that they are rather local adornments than items brought there by a particular population. Their distribution area is extremely broad and develops on a sufficiently long chronological interval, namely at least from the tenth century until the thirteenth century. If we consider the items from cemeteries investigated in wide areas of South-Eastern Europe, one can see that these rings are not numerous and are mainly concentrated in the Carpathian Basin, Southern Poland, Croatia, while they are rare in the south of the Lower Danube and absent in the area located to the south and east of the Carpathian Mountains. Moreover, they are absent from most cemeteries in which prevail the Byzantine adornments from the north of the Danube, dated to the eleventh-thirteenth centuries, investigated on the territory of Banat. The presence of these items on the territory of Romania reflects rather a fashion trend. It cannot have a particular ethnic feature. The beginnings of their use should be sought at least during the tenth century. The absolute chronology, based on the coins found inside the graves, indicates the use of the items from the reign of King Stephen I to the reign of King Stephen III. It has been observed that inside the graves they usually occurred on the right hand fingers of the deceased. The anthropological analysis and the association with other inventory items indicate their presence especially in graves of women and sporadically in graves of children or adolescents. Overall, one can notice the absence of weapons inside the graves, except for three graves in which knives were deposited. In terms of items in the cemeteries, it can be noticed that, regardless of region, Byzantine items or their imitations also occur almost invariably. However, they are hardly ever associated with items derived from the ones of the steppe horizon of the tenth century. Exceptions are some graves that had these rings as grave goods. This could indicate that the twisted rings and their imitations are a commodity or a local product that reflect the preference of some communities which used this type of adornments.

\author{
Ph. Dr. Silviu Oța \\ National Museum of History \\ Calea Victoriei 12 \\ Bucharest, 030026 \\ Romania \\ silviuota@yahoo.com
}


Silviu OȚA

\section{Appendix/Prílohy}

Pl. 1. Territorial distribution of rings. / Tab. 1. Územné rozšírenie prsteňov.

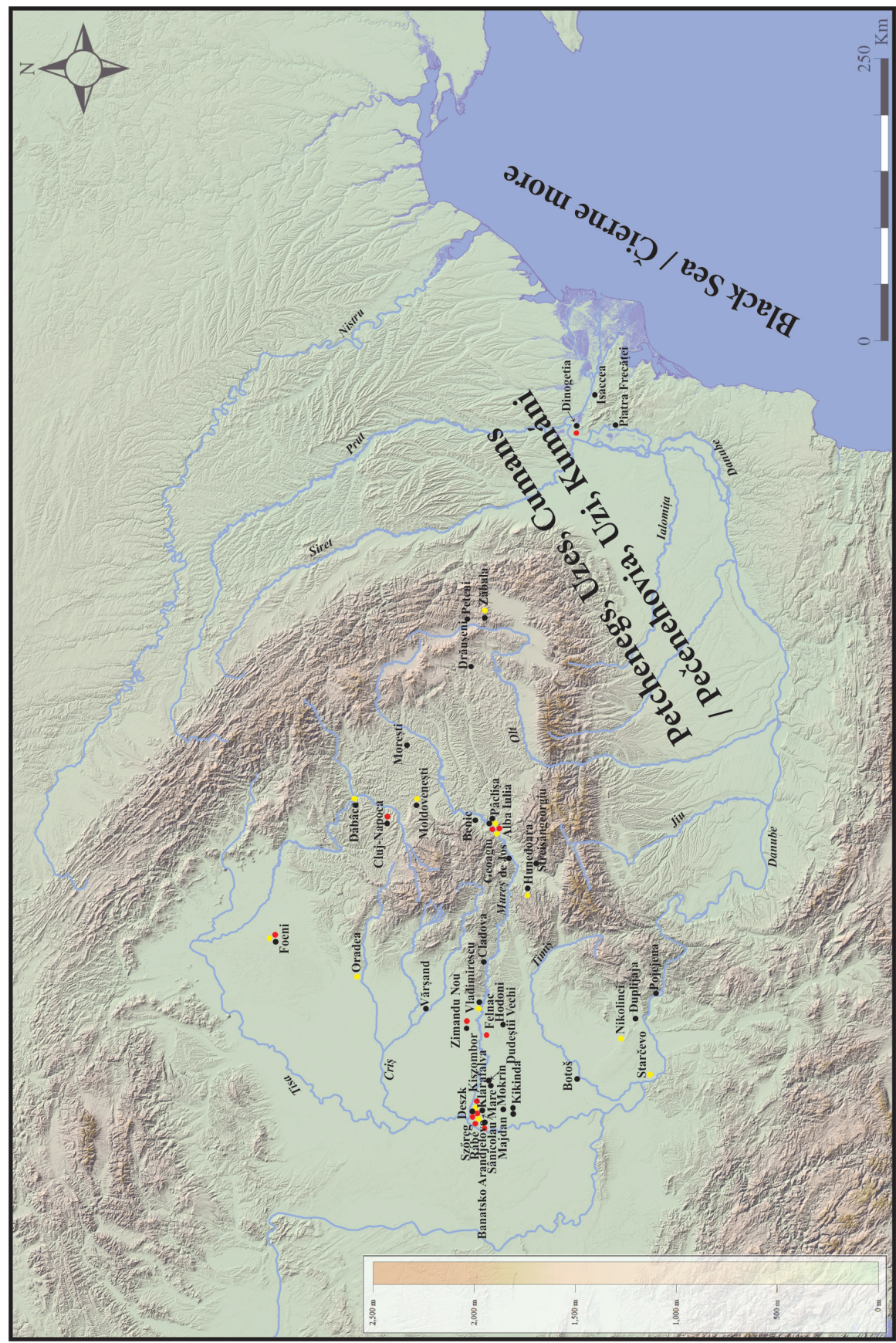

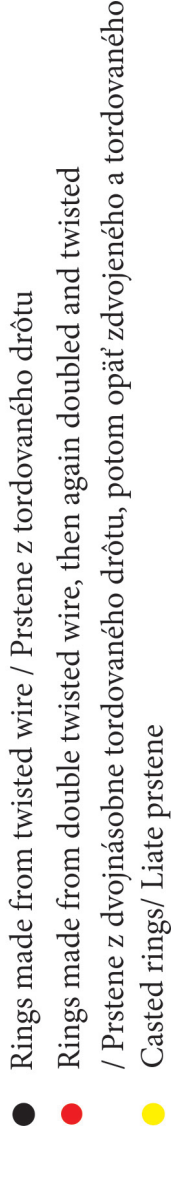


Pl. 2. The typology of gold and silver rings. / Tab. 2. Typológia zlatých a strieborných prsteňov.

I. Twisted wire rings / Tordované drôtené prstene

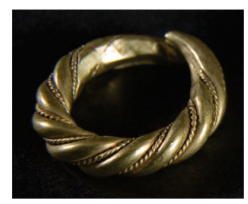

I.1. Gold / Zlato: Garvăn-Dinogetia (photo by / fotografia od: Marius Amarie)

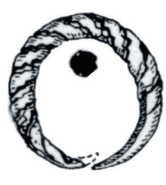

\section{I.2.1.1. Silver / Striebro: Garvăn-Dinogetia (according to / podla Ştefan et al. 1967)}

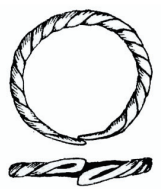

I.2.1.3. Silver / Striebro: Alba Iulia-Str. Brânduşei, Termele Romane, Catholic Cathedral / Rímskokatolícka katedrála, Cluj -Napoca-Mănăştur Hunedoara-Dealul cu Comori Majdan, Moldoveneşti, Ostrov-Piatra Frecăței, Streisângeorgiu (according to / podla Popa 1976), Zăbala
I.2.1.4. Silver / Striebro: Alba Iulia-Roman Baths / Rímske kúpele, Banatsko Arandjelovo (according to / podla Stanojev 1989)

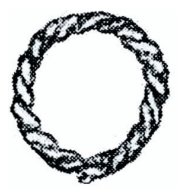

I.2.1.2. Silver / Striebro: Alba Iulia-Str. Brândușei,

Termele Romane,

Catholic Cathedral /Rímskokatolícka katedrála, Banatsko Arandjelovo (1903),

Botoš-Mlaka, Foieni,

Garvăn-Dinogetia,

Hodoni-Pocioroane

(according to / podla

Țeicu 1996), Zimandul Nou

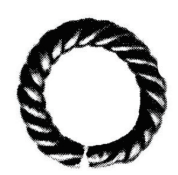

\section{I.2.1.5. Silver / Striebro:} Pojejena

(photo by / fotografia od: Silviu Oța) 
Pl. 3. The typology of bronze rings. / Tab. 3. Typológia bronzových prsteňov.

I. The twisted wire rings / Tordované drôtené prstene

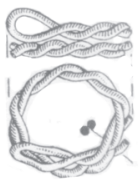

I.3. Bronze / Bronz:

I.3.1.1. Garvăn-Dinogetia (according to / podla Ştefan et al. 1967)

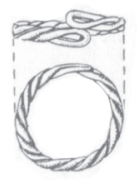

I.3.2.2. Garvăn-Dinogetia (according to / podla Ştefan et al. 1967)<smiles>c1ccccc1</smiles><smiles>c1ccc2c(c1)sc1c2ccc2scnc21</smiles>

I.3.1.2. Dudeștii Vechi (according to / podla Bejan et al. 2005), Geoagiu de Jos

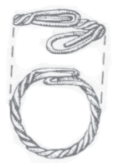

I.3.2.3. Garvăn-Dinogetia (according to / podla Ştefan et al. 1967), Isaccea
I.3.2.1. Isaccea, Garvăn-Dinogetia, Felnac Hodoni-Pocioroane (according to / podla Bejan-Moga 1979), Pădureni, Pâclișa,

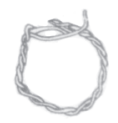

Other rings / Ostatné prstene (according to / podla Ștefan et al. 1967)

II. The twisted wire rings (double twisted, then again doubled and twisted)

/ Tordované drôtené prstene (dvojnásobne tordované, potom opät zdvojené a tordované)

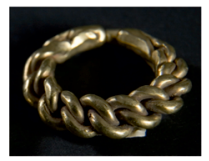

II.1. Gold / Zlato: Garvăn-Dinogetia (photo by / fotografia od: Marius Amarie)

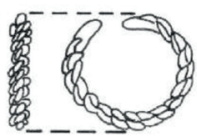

II.2. Gilded silver / Pozlátené striebro: Alba Iulia-Str. Brânduşei (according to / podla Dragotă et al. 2009)



II.4.Bronze / Bronz: Isaccea (according to / podla Vasiliu 1984), Kiszombor-C, Klárafalva-B, Szőreg-Distilerie 
Pl. 4. The typology of casted rings (silver and bronze). / Tab. 4. Typológia (strieborných a bronzových) liatych prsteňov.

III. The casted rings / Liate prstene

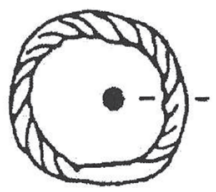

III.1. Silver / Striebro:

III.1.1. Nikolinci (according to / podla Živković 1997)
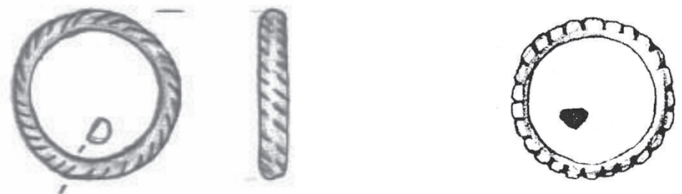

III.1.2. Alba Iulia-Str. Brândușei (according to / podla Dragotă et al. 2009) Oradea-Galca Ghețărie

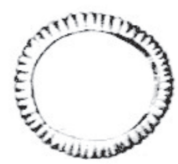

III.1.2.2. Hunedoara-Dealul cu Comori (according to / podla Roska 1913)

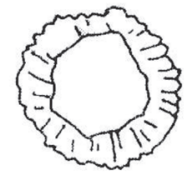

III.2. Bronze / Bronz:

III.2.1.Moldovenești, Oradea-Salca Ghețărie, Rábé [according to / podla Kovács 1991-1992 (1992)]
III.2.2. Bronze / Bronz:

Dăbâca Moldovenești

(according to / podla

Roska 1914), Starčevo-Livade 